\title{
Chapter 7 \\ Influence of Reading Habit on Student Academic Performance in a Senior Second School in Ibadan
}

\author{
Grace Adeola Popoola \\ National Open University of Nigeria, Nigeria \\ Oluwafunmilayo Kunbi Amoo \\ Bowen University, Iwo, Nigeria \\ Ojoma Gloria Umar \\ Kogi State Univeristy, Nigeria \\ Ayobami Abayomi Popoola \\ (iD) https://orcid.org/0000-0002-9742-0604 \\ University of KwaZulu-Natal, South Africa \\ Olaronke Modupeoluwa Olatunji \\ HillCrest High School, Nigeria
}

\section{ABSTRACT}

Secondary school as a gateway for the development of other sectors of the educational system provides primary school leavers with the opportunity for qualitative education, the platform for skills and knowledge for vocational work, or higher institutions admission. In Nigeria, public discussions frequently focus on educational standards. This study aims to examine the influence of students' reading habits on students' academic performance. A descriptive survey design was adopted. The schools in Ibadan North LGA were randomly selected, making a total of five schools. Each of the participants was randomly selected, totaling 300 students. There was DOI: 10.4018/978-1-7998-4906-3.ch007 
a significant positive relationship between student reading habits and student academic performance $(r=0.84)$. At $F=1.31$, there is no significant difference in the reading habit of male and female students. Reading habit enhances the academic performance of students. Therefore, students should be encouraged to inculcate in them the reading habit by providing enabling environment and infrastructures that will stimulate students to read.

\section{INTRODUCTION}

The Federal Government of Nigeria, through the Federal Ministry of Education (FME) (2004), in the National Policy on education highlighted the broad aims of secondary education as preparing students to play their role by contributing to the nations' economic, political and social development and sustainable goals, for useful living within the society and preparing them for higher education. Secondary school is generally considered the gateway for the development of other sectors of the educational system. It provides primary school leavers the opportunity for qualitative education and provides the platform from which higher institutions draw students for admission into their various programs. It also provides students who will not go for higher education in the colleges' and university's skills and knowledge for vocational work.

In Nigeria, public discussions frequently focus on educational standards. The public's unhappiness becomes more prominent in the reported cases of poor and continued decline in the academic performance in the Senior School Certificate Examination across Nigeria (Umameh, 2011; Alimi et al., 2012; Ajayi and Osalusi, 2013; Duruji et al., 2014) as student outcomes did not match the government and parental investments. In the view of Duruji et al. (2014), their study reported that student non-commitment and quality of teaching had been a limitation to excellent academic performance. With the reported incidence of examination malpractice (Adeniyi et al., 2010), the low level of commitment among students, as mentioned by Duruji et al. (2014), cannot be downplayed. All stakeholders are concerned about why the system is turning out students with poor results. Authors (Ogunsaju, 2004; Owoeye and Olatunde, 2011; Bertoni et al., 2017; Taylor et al., 2017; Ibrahim et al., 2017; Suleiman et al., 2019) states that the academic standard in all Nigerian educational institutions has fallen considerably below societal expectations. Blumende (2001) corroborated this view when he reported that the decline in the quality of education could not be ignored by anyone aware of the significant role of education as an instrument of societal transformation and development. Bertoni et al. (2017) traced the decline in education in Nigeria to the increasing incidence of communal conflicts, which has resulted in displacement and forced migration and relocation. 
The poor state of Nigerian secondary schools calls for concern. Many educators (Usman, 2015; Kayode and Ayodele, 2015; Igboanusi and Peter, 2016) have observed in the recent past that secondary schools have derailed in the provision of qualitative education expected of them. Igboanusi and Peter (2016) reported the public mass knowledge of senior school students' failure. Many problems seem to bedevil the system, thereby affecting student academic performance. Student academic performance needs to be high in order to meet the country's goal for political, economic, and socially sustainable development. The extent to which the school system can accomplish its stated objectives of the national policy on education determines its level of effectiveness. It has, however, been observed that students are not doing well in the secondary education level, and this seem to make the society lose confidence in the educational system. For instance, student academic performance, which members of the society used mainly to measure the effectiveness of schools, has witnessed unprecedented setbacks. Studies (Ezenwafor and Amobi, 2016; Musah et al., 2017) have shown in their studies the extent of poor academic performance of students in external examination. Musah et al. (2017) mentioned that for science subjects such as Biology, there had been an increasing concern for the public. Ezenwafor and Amobi (2016) reported the same for business-oriented subjects. In their study, improved parental support and study habit were suggested.

Studies (Akibuiro and Joshua, 2004; Abdu-Raheem, 2015) reported that the academic performance of secondary school students in the South-Western region of Nigeria is poor. As Chauhan (2003) puts it, poor school achievement is a behavioural deviation that is symptomatic of maladjustment. Similarly, national policy on education FME (2004) and Okegbile (2003) noted that students' achievement is not only focused at preparation for a useful living but also eligibility for higher education, which are attainable through excellent study skills, attitudes or methods.

Achievement processes have been viewed by the characteristics of students and their environments, utilization of teaching-learning models, instructional materials as well as the structural ability of the students. Several factors have been linked with poor academic performance of students, which include poor reading or study habits of a student. An Individual's studying pattern/behaviour affect the amount of information that such an individual adds to his or her short and long term memory. In promoting academic excellence, study habits (Gbore, 2006a\&b) and factors such as effective use of time, student concentration, learning procedure, and consultations (Adeyemo, 2005) have been identified to dictate the academic performance of students.

In Nigeria, the poor academic performance of secondary school students with its negative consequences has been of concern to many parents, teachers, counsellors, and educational administrators. The poor academic performance has been attributed to lack of adequate teaching facilities, unqualified teachers, students' poor study habits, psychological adjustment problems such as anxiety, stress, and depression, 
and students' lack of financial support such as scholarships, bursary awards, and loans. The problem in the educational system has been attributed to factors such as poor remuneration of teachers, academic dishonesty, lack of school physical facilities, and underfunding. Others are industrial disputes and corruption among teachers, school administrators, and civil/public servants in Ministries of Education. The numerous problems permeating the entire educational system in Nigeria to be addressed considering the importance of education to national development. Hence, this study intends to examine the influence of reading habits on the academic achievement of students in Ibadan North local government.

\section{Hypotheses}

$\mathbf{H}_{\mathbf{o 1}}$ : There is no significant relationship between student reading habits and student academic performance

$\mathbf{H}_{\mathbf{0} 2}$ : There is no significant difference in the reading habit of male and female students

\section{OPERATIONAL DEFINITION OF TERMS}

1. Study Habit: This is a behavioural style that is systematically formed by students towards learning and achievement. According to Ghulam (2013), study habits are the students' way of study, whether systematic, efficient, or inefficient. It is viewed that good study habits are perceived to be the determinants of academic performance. According to Prof. Dr. Thomas Wilmer in Ghulam (2013), study behavior is mental readiness to learn. It is organized through experiences, objects, and situations in the study. That means with the information and Solutions of the Problems to keep the study behavior for academic goals positive.

2. Study Skills: These are peculiar strategies developed by the students in studying.

3. Academic: This has been variously defined, but for this study, academics are defined as college studies or learning; in other words, it designates the intellectual aspect of education, particularly the final subject, which deals with organized knowledge.

4. Academic Performance: This refers to the performance that falls within a specified standard. The specified standard is usually called pass mark, and the pass mark is a score above average in which students are considered having passed and below which students are considered having failed. Ghulam (2013) asserted that the performance of education besides other factors depends upon study habits and study behavior of Students. Furthermore, the quality of education is reflected through motivation, which is a function of study habits 
and study behavior of students. A positive or adverse reaction to a specific object of the study represents the study behavior.

5. Student: A person who is learning or studying at a place of higher or further education. Without someone being a student, such a person cannot be said to have study skills and habits. Without a person targeting a particular thing, which in most cases is to be educated, there cannot be a performance to measure.

From the above, all the terms defined above are a function of the zeal to learn or to be a student.

\section{METHODOLOGY}

The study employed a descriptive survey design.

Participants: A sample size of 300 students who were randomly selected from five senior secondary schools participated in the study

Instrument: A self-constructed questionnaire was designed to elicit the necessary information from respondents. The questionnaire was divided into four sections. The first part was on the demographic characteristics and the socio-economic status of the respondents, while the second part elicits information on the reading pattern of the students. The third part gathers information on the study habit on the students. The last section elicits information from the respondents on the factor affecting the reading habits of students. Test-retest reliability was carried out using the PearsonProduct Moment Correlation coefficient, which gave a value of 0.856 for two weeks, and this was meant to ensure the stability of the scores over a while.

Method of Data Collection: Based on the human sensitivity of the students, five classroom teachers were interviewed and also served as support staff in the administering of the questionnaires.

Method of Data Analysis: Data was analyzed using inferential statistics. The inferential statistics used were the Spearman Rank Correlation Coefficient Technique and ANOVA.

\section{Results}

The results of the study are presented here

\section{Hypothesis 1}

$\mathbf{H}_{\mathbf{o 1}}$ : There is no significant relationship between student reading habits and student academic performance. 
Table1 shows that there was positive significant relationship between student reading habit and student academic performance $(\mathrm{r}=0.84, \mathrm{~N}=300, \mathrm{P}<.05)$. Therefore, the alternative hypothesis is accepted, and the null hypothesis is rejected.

Table 1. Correlation between Students' Reading Habit and Students' Academic Performance.

\begin{tabular}{|l|c|l|l|l|l|l|}
\hline & Mean & S.D & N & \multicolumn{1}{|c|}{$\mathbf{R}$} & $\mathbf{P}_{\text {-value }}$ & Remark \\
\hline Reading habit & 14.6167 & 2.32977 & \multirow{2}{*}{300} & \multirow{2}{*}{0.84} & $<0.05$ & Sig. \\
\hline Academic performance & 1.8167 & 0.76047 & & & & \\
\hline
\end{tabular}

Source: (Authors' Compilation)

\section{Hypothesis 2}

$\mathbf{H}_{\mathbf{0} 2}$ : There is no significant difference in the reading habit of male and female students on students' academic performance

Table 2. Analysis of Variance of Reading Habit of Male and Female Students on Students Academic Performance

\begin{tabular}{|c|c|c|c|c|c|c|}
\hline Gender & $\mathbf{N}$ & Mean & SD & $\mathbf{F}$ & $\mathbf{P}$ & Remark \\
\hline Male & 145 & 14.3172 & 2.41438 & \multirow{2}{*}{1.31} & \multirow{2}{*}{$>0.05$} & \multirow{2}{*}{ Not significant } \\
\hline Female & 155 & 14.8968 & 2.21909 & & & \\
\hline \multicolumn{3}{|c|}{ Dependent variable } & \multicolumn{4}{|c|}{ Reading habit } \\
\hline
\end{tabular}

Source: (Authors' Compilation)

The table shows that at $\mathrm{F}=1.31$ and $\mathrm{P}>0.05$, there was no significant difference in the reading habit of male and female students. Therefore, the alternative hypothesis is rejected, and the null hypothesis is accepted.

From the test of the two hypotheses set, the results showed that there was a significant positive relationship between student reading habits and student academic performance $(r=0.84, \mathrm{~N}=300, \mathrm{P}<.05)$. Although the relationship did not account for any significant difference across gender as the analysis shows that at $\mathrm{F}=1.31$ and $\mathrm{P}>0.05$, there was no significant difference in the reading habit of male and female students. 


\section{READING HABIT OF STUDENTS}

The concepts study habits, study method, learning method, study skill, learning skill, and study attitude have been used differently and sometimes interchangeably. However, the common characteristic of these concepts is the objective behind their theoretical and practical explanations, which is directed towards enhancing students' academic achievement (Biggs, 1970; Brown and Holtzman, 1976; Northey et al., 2018; Albrecht and Karabenick, 2018). Study habit in this context is a behaviour style which is systematically formed by students towards learning and achievement. Bojuwoye (1993) asserted that one major area in which students need preparation in order to improve their performance is in learning how to study. That lack of adequate study habits is a common educational problem among secondary school students.

Study habits are learning tendencies that enable students to work privately. Ikegbunam (1998) identified 'making of study time-table' as one of the study 'skills' for students. It is a propeller of better academic performance. This suggests that study habit can either be excellent or poor; hence, Vipene (2005) opines that good study habits are assets to the leaner because they (habits) assist students to attain mastery in areas of excellent performance while the reverse constitution constraints to learning and achievement leading to academic failure. Slain (2000) in Agina-Obu et al. (2011) explain that study habits help to develop necessary student skills amid at improvement in reading, comprehension, and examination performance.

An effective study technique (habit) could, therefore, be seen as a goal-oriented or result-determined and systematically patterned way a student willingly and consistently adopts in his private studies with a view to attaining success in his academic activities. It could also be regarded as a success-driven device consciously and consistently adopted by a student in his private study engagement in order to achieve excellence in his period of academic tutelage. From the preceding, therefore, he cannot achieve this without the awareness and use of various effective study techniques (Habits).

Table 3 shows the study habit of the respondents. The researchers based on the secondary school experience as an educator and the forty-five minutes scheduled for each subject taught in the school investigated the students' study habits. The result shows that the distribution of the study habit of the students interviewed. From the sample, some $7.3 \%$ find it difficult to private study of 45 minutes. These 22 students raise perceived classroom concerns for the teachers and educators. The students' level of assimilation and capacity to sustain reading for this period is a significant concern as many find it challenging to have a complete forty-five minutes study. Based on an interview with some class teachers, one interviewee reported that in some instances, a class teacher must incorporate visual renditions against complete aural to accommodate some students that may be easily distracted before the forty- 
five minutes subject tutorial time elapses. Although the table also reveals that some (11.7\%) students might find it difficult to get serious during study time. This can be traced to uncoordinated study time among $16.3 \%$ of the students. The researchers raise issues of uncoordinated study time among many students, as this might limit the effectiveness of study among uncoordinated students. Chand (2013) mention the dimension that study habit brings when subjects are planned for. The argument is that the students defer in their capacity to plan and coordinate their study pattern.

\section{Table 3. Secondary students study habits in Ibadan North LGA}

\begin{tabular}{|c|c|c|c|}
\hline $\mathbf{S} / \mathbf{N}$ & ITEMS & YES & NO \\
\hline 1 & Are you able to study for a sustained period (at least forty-five minutes)? & $278(92.7 \%)$ & $22(7.3 \%)$ \\
\hline 2 & Are you in the habit of getting right down to serious work at study time? & $265(88.3 \%)$ & $35(11.7 \%)$ \\
\hline 3 & $\begin{array}{l}\text { Do you arrange your study time and area so that distractions and } \\
\text { interruption are minimized? }\end{array}$ & $251(83.7 \%)$ & $49(16.3 \%)$ \\
\hline 4 & Are you in the habit of reviewing each subject regularly during the term? & $257(85.7 \%)$ & $43(14.3 \%)$ \\
\hline 5 & Do you prepare for examination without cramming? & $211(70.3 \%)$ & $89(29.7 \%)$ \\
\hline 6 & When preparing for exams, do you outline your course work? & $240(80.0 \%)$ & $60(20.0 \%)$ \\
\hline 7 & $\begin{array}{l}\text { Are you able to anticipate important topics that might be covered on } \\
\text { exams? }\end{array}$ & $274(91.3 \%)$ & $26(8.7 \%)$ \\
\hline 8 & $\begin{array}{l}\text { Do you make it a habit to prepare possible answers to essay questions in } \\
\text { advance? }\end{array}$ & $257(85.7 \%)$ & $43(14.3 \%)$ \\
\hline 9 & Do you study regularly at a regular study time? & $240(80.0 \%)$ & $60(20.0 \%)$ \\
\hline 10 & Do you schedule your time intelligently to cover all subjects? & $249(83.0 \%)$ & $51(17.0 \%)$ \\
\hline 11 & $\begin{array}{l}\text { Do you schedule social activities so that it will not interfere with } \\
\text { studying? }\end{array}$ & $247(82.3 \%)$ & $53(17.7 \%)$ \\
\hline 12 & Do you rest adequately so that fatigue does not reduce efficiency? & $239(79.7 \%)$ & $61(20.3 \%)$ \\
\hline 13 & $\begin{array}{l}\text { Do you recognize the need to devote extra time to over learn certain } \\
\text { subjects? }\end{array}$ & $240(80.0 \%)$ & $60(20.0 \%)$ \\
\hline 14 & Are you able to concentrate in class? & $293(97.7 \%)$ & $7(2.3 \%)$ \\
\hline 15 & Are you able to listen while taking notes? & $226(75.3 \%)$ & $74(24.7 \%)$ \\
\hline 16 & Do you use the library regularly? & $113(37.7 \%)$ & $187(62.3 \%)$ \\
\hline 17 & Are you able to isolate and learn definitions? & $277(92.3 \%)$ & $23(7.7 \%)$ \\
\hline 18 & Do you make it a habit to review daily for each class? & $228(76.0 \%)$ & $72(24.0 \%)$ \\
\hline
\end{tabular}

Source: (Authors' Compilation)

From Table 3, the majority $(85.7 \%, 70.3 \%, 80 \%$, and $91.3 \%$ ) reported to engage in the habit of reviewing each subject regularly during the term, adequate preparation without cramming, outline their course work when preparing for exams towards 
the anticipation of topics to expected in the examination respectively. Many of the students reported that they prepare a draft of possible essay questions in advance in a way that they make efficient use of their time to cover all subjects intelligently. The result reveals about 2 out of every ten respondents do outline their course work when preparing for examination; do study regularly at a regular study time; do rest properly so that fatigue does not reduce efficiency and do recognize the need to devote extra time to over learn specific subjects. Also, almost all the respondents can concentrate in class; this shows that the inability to concentrate in class is not a problem among the respondents. It can also be observed that more respondents do not use the library regularly compared to those that use the library regularly. Furthermore, about 3 out of every ten respondents cannot prepare for examination without cramming.

\section{PATTERN OF READING HABIT OF STUDENTS IN SECONDARY SCHOOL}

Reading habits, for this study, are defined as how often, how much, and what students read. Over the years, researchers have devoted efforts to examining learners' reading habits concerning gender (Scales and Rhee, 2001; Razia, 2015; McGeown, 2015), income (Razia, 2015), age (McGeown, 2015), educational background (van Bergen et al., 2017), employment status (Ahmad et al., 2014), and career and professional growth (Womack and Chandler, 1992; Wood et al., 1995; Erdem, 2015). McGeown (2015) opine that teacher awareness of gender and age differences is a crucial factor in encouraging reading habits among adolescents. Studies (Stanchfield and Fraim, 1979; Scales and Rhee, 2001; Summers, 2013; McGeown, 2015) reported that choice of what to read ranges from automobiles, physical and masculine activity, sports, occupations, music, and travel for males and sexes, shopping, cooking, advertisements, Bible, magazine cartoons, and comic books for females. Despite the diversity in the choice of what to read, Patterson (1986) iterates that girls devote more time to reading than boys.

The quality of time spent and reading habits often determine varied on academic performance. Especially as a technological effect on reading presents mixed results (Caverly and Peterson, 2000). For instance, Sheorey and Mokhtari (1994) indicated that there is no significant difference between high and low-proficient readers about the amount of time spent reading academic or nonacademic materials, Gallik (1999) study established a positive relationship between students' cumulative grade-point average and time spent reading for pleasure during vacations. Also, in a study that comprised of 600 secondary school pupils across 100 secondary schools, Ogunrombi and Adio (1995) found that home conditions did interfere with reading. The study 
contends what the authors' termed "induced reading" owing to the rigid time table, well-structured reading venues, clubs, and libraries, and update reading resources (professional teacher and librarians, equipment, and materials) that are available to encourage student reading culture. Ameyaw and Anto (2018:1) narrated that the lack of a conducive home environment hinders their reading habits $t$ when they are at home. Their study suggested that parents should help their children to have a serene reading environment when they are at home. This finding aligns with the views of Morrison and Cooney (2001), who iterates that conducive home conditions towards learning and studying provide a necessary emotional and psychological stability for students. Le et al. (2019) further mentioned that home condition often dictates the choice of reading and the time spent to read.

The study attempts to examine students' reading patterns. The authors' classified the sources of reading materials based on the country experience and preliminary informal discussions with the classroom teachers of the schools that were sampled for the study.

Table 4. Frequency of reading according to material sources

\begin{tabular}{|c|l|l|l|l|l|l|}
\hline S/N & \multicolumn{1}{|c|}{ ITEMS } & \multicolumn{1}{|c|}{ Never } & \multicolumn{1}{c|}{ Rarely } & \multicolumn{1}{c|}{ Sometimes } & \multicolumn{1}{c|}{ Often } & \multicolumn{1}{c|}{ Very often } \\
\hline 1 & Newspaper & $16(5.3 \%)$ & $56(18.7 \%)$ & $169(56.3 \%)$ & $41(13.7 \%)$ & $18(6.0 \%)$ \\
\hline 2 & Magazines & $33(11.0 \%)$ & $52(17.3 \%)$ & $150(50.0 \%)$ & $51(17.0 \%)$ & $14(4.7 \%)$ \\
\hline 3 & Textbooks & $2(0.7 \%)$ & $22(7.3 \%)$ & $44(14.7 \%)$ & $133(44.3 \%)$ & $99(33.0 \%)$ \\
\hline 4 & Class notes & $4(1.3 \%)$ & $20(6.7 \%)$ & $32(10.7 \%)$ & $95(31.7 \%)$ & $149(49.7 \%)$ \\
\hline 5 & Novels & $16(5.3 \%)$ & $52(17.3 \%)$ & $95(31.7 \%)$ & $74(24.7 \%)$ & $63(21.0 \%)$ \\
\hline 6 & Email & $103(34.3 \%)$ & $59(19.7 \%)$ & $69(23.0 \%)$ & $35(11.7 \%)$ & $34(11.3 \%)$ \\
\hline 7 & Online information & $59(19.7 \%)$ & $60(20.0 \%)$ & $78(26.0 \%)$ & $51(17.0 \%)$ & $52(17.3 \%)$ \\
\hline
\end{tabular}

Source: (Authors' Compilation)

From the analysis, Table 4 shows the distribution of the reading pattern of students. The result shows that the majority of the respondents sometimes read newspapers and magazines. When student choices of reading a textbook and class notes were made, it was revealed that the majority of the respondents sometimes read their class notes compare to textbooks and other kinds of material. The reading of emails was quite low based on the analysis (Table 4), which shows that only 69 respondents out of the 300 respondents sometimes read emails. It can be discovered from the result that a majority $(34.3 \%)$ of the respondents never read emails. Also, the majority (56.3\% and 50.0\% respectively) of the respondents sometimes read newspapers and magazines. Most of the often read textbooks but read their notebooks very often. 
The result also reveals that the respondents do not consult or read other material much except their textbooks and class notes, this is more important considering the amount of information available online on the internet, and they rarely consult it. This is asserted by only $34.3 \%$ that regularly consult online related educational information. Esther and Oluwatoyin (2018) pointed that despite the relevance of information communication technology of education development, the focus is placed on the financial (legal and illegal) and social relevance of the online information bank. It was iterated that why the internet service might not be readily available in some schools, the use among the students for educational related learning and reading is limited. Situated within the discussion of Arohunmolase (2006), where Yoruba language and has been trending on the global scene, the relevance of the internet and email cannot be downplayed. Idehen and Oshodin (2008) identified that all the necessary learning materials are key to both learning and teaching.

This internet material limitation is further affected by a lack of reading material and textbooks in many of the public secondary schools. Observation revealed that access to the textbook is often based on private individual access to text materials, as most teachers depend on repeatedly used reading material. Studies by Adebayo (2001), Idehen and Oshodin (2008), and Owoeye and Olatunde (2011) all point to lack or weak development of textbook that speaks to the education quality and sustainability in Nigeria. In the view of Nwafor and Umoke (2016), aver the access and use of quality textbooks towards improving students' education and teachers' teaching process. Willaims (2016) iterated this when it was mentioned that education regulating the body must create ensure the quality of the textbook used for the teaching must be up to standard.

\section{STUDENT READING CULTURE AND ACADEMIC PERFORMANCE}

Access to information is crucial to individual advancement as well as corporate, educational development. Information is indispensable, and it bridges the gap between knowledge and illiteracy (Yusuf, 2007). Kolawole (2005) sees reading as the fulcrum or cornerstone of literacy, and that without it, there can be no literacy. Reading offers a productive approach to human development as it is the foundation upon which other academic skills are built. Tella and Akande (2007) assert that the ability to read is at the heart of self-education and lifelong learning and that it is an art capable of transforming life and society. Yani (2003) posits that reading habits of Nigerians are a matter of concern in our educational and national development, stating further that in a developing country like Nigeria, the concept of reading habits should not be relegated to the background. 
Reading is the bedrock of any formal form of education. It is a cornerstone of any academic endeavour or success. Its proficiency is the royal road to knowledge and success in all academic subjects. Kolawole (2005) also noted that reading is fundamental to learning, and so a child's ability to read is the centre of the education process. The complexity of reading is mainly geared at recognising and understanding written and printed words (Mabekoje, 2005). It is essential in all phases of life because of the practical purposes it serves. Therefore, if the child must develop well as a social being, he needs to cultivate desirable reading attitudes and interests.

To ascertain if there is a relationship between reading interests and reading achievement, scholars, and teachers have all along with advanced possible causes of low or under-achievement of students in school subjects. Subject teachers have concentrated on diagnosing textbooks used, teachers' method and personality, difficult concepts, curriculum contents, among others, as influencing students' performance. However, educational researchers have identified poor motivation, study habit, attitude, planning (pre- and post- by teachers and students), adjustment, and lack of self-concept, among others as possible causes of poor academic achievement (Akinboye, 1974; Emeke, 1984; Ezewu 1987; Oheari, 1994; Akinsolu, 2010). A study by Aduwa (2004), on determinants of students' academic success, reported that a student's home environment, their cognitive abilities, self-esteem, self-concept, study habits, and motivation affect their academic success. Contrary to this, Iyamu (2005) contended that the provision of all these factors might not have a significant impact on successful learning if the learners are not exposed to competent principals, teachers, and other school teams.

\section{FACTORS INFLUENCING STUDENTS READING HABIT}

Reading habits are the practices of people to seek reading material and devote time to reading deliberately. The need for information and knowledge motivates people toward reading. Reading is a source of pleasure, intellectual satisfaction, and knowledge attainment. There are two types of non-readers, those who know how to read but do not read enough, and those people who have not been trained to read. There are many reasons for these poor study habits and attitudes. This includes absence of a reading culture, illiteracy, weak purchasing power, weak education system and inadequate library systems, poor preparation of teachers, lack of interest, poor libraries, absence of a conducive reading environment, home background, unmotivated library staff, non-availability of required reading material, lack of adult readers as models, lack of resource materials (Ojo, 2003). Jung (2016) mentioned that why there is no clear implication of male reading role models among students as investigated, the change in the overall reading attitude cannot be ignored as the 
intervention brought about a better appreciation in the reading activity. Applegate and Applegate (2004) mentioned that the peter effect might better serve as a means of promoting student reading engagement by teachers as they are pupils, main role models. Mansor (2013:363) mentioned that good role modeling by mothers who are themselves readers have an additional impact on sealing-in the potential reading habit. The argument here is that parents as role models are better reading influencers for students.

The relevance of the environment (home, physical, parent interest and structure of study time) that are conducive for developing reading habits among students has been contended by Iftikhar (2002, pp. 21-26). Iterating the environment effect, a comparative study between high and low socio-economic status students parents' in Ile-Ife, Nigeria by Lasisi and Adeyanju (1991) revealed a variance in story preference among school pupils. Evidence shows that low-income primary two children showed high interest in fairy tales and in stories that focus on animals. At the same time, their high-income counterparts preferred stories based on the foreign (western) culture, although they also preferred animal stories. The researchers thus inferred that both socio-economic status and cultural background seemed to influence the learners' reading preferences.

Obafemi (2006) opined that the unsustainable economic condition of the country, which has subjected many citizens to poverty, indirectly dictates reading culture among Nigerians. The perception is that reading was expensive and had become leisure; most people could ill afford it. Also, the in-thing, according to him, was that people prefer to stay in their homes and watch home videos. Commeyras (2001) sermonize the downtrodden nature of the quest for education and knowledge owing to weak socio-economic level and quality of life. She recommended an anthropological approach to the concept of reading, meaning the examination of the broader existing culture in which reading is to be promoted. This is because, according to her, it has been acknowledged that there may be values in the broader culture that interfere with the culture of reading that is being promoted-Nigerians like talking and interacting socially when they are in the company of one another. Reading is individualistic and is bound to meet with specific difficulties since Africans find it idle and boring.

Responding to the research question of what factors influence students' habits, the researchers developed a Likert scale based on some identified modifiable factors from literature discussed above. Table 5 shows that about $78 \%$ of the respondents believed that the home environment as a significant influence on students reading habits. Narrating this, a teacher reported that there where instances when experiences of students at home affect their performance, assimilation, and reading habit. This was explained as about 6 out of every ten respondents believe parental interest affect the respondents' reading habit. In the same vein, 3 out of every ten respondents do not believe that physical environment do influence student reading habit. 
Influence of Reading Habit on Student Academic Performance in a Senior Second School

Table 5. Modifiable factors that influence students study habits

\begin{tabular}{|l|l|c|c|c|c|}
\hline S/N & \multicolumn{1}{|c|}{ ITEM } & SA & A & D & SD \\
\hline 1 & Home environment & $100(33.3 \%)$ & $135(45.0 \%)$ & $36(12.0 \%)$ & $29(9.7 \%)$ \\
\hline 2 & Parent's interest & $77(25.7 \%)$ & $118(39.3 \%)$ & $64(21.3 \%)$ & $41(13.7 \%)$ \\
\hline 3 & Physical environment & $68(22.7 \%)$ & $137(45.7 \%)$ & $73(24.3 \%)$ & $22(7.3 \%)$ \\
\hline 4 & Distribution of study time & $76(25.3 \%)$ & $129(43.0 \%)$ & $53(17.7 \%)$ & $42(14.0 \%)$ \\
\hline 5 & Absence of a reading culture & $97(32.3 \%)$ & $107(35.7 \%)$ & $59(19.7 \%)$ & $37(12.3 \%)$ \\
\hline 6 & Illiteracy & $102(34.0 \%)$ & $83(27.7 \%)$ & $70(23.3 \%)$ & $45(15.0 \%)$ \\
\hline 7 & Poor purchasing power & $73(24.3 \%)$ & $104(34.7 \%)$ & $78(26.0 \%)$ & $45(15.0 \%)$ \\
\hline 8 & $\begin{array}{l}\text { Weak education system and inadequate } \\
\text { library system }\end{array}$ & $97(32.3 \%)$ & $120(40.0 \%)$ & $50(16.7 \%)$ & $33(11.0 \%)$ \\
\hline 9 & Absence of conducive reading environment & $85(28.3 \%)$ & $130(43.3 \%)$ & $59(19.7 \%)$ & $26(8.7 \%)$ \\
\hline 10 & $\begin{array}{l}\text { Non-availability of required reading } \\
\text { material }\end{array}$ & $85(28.3 \%)$ & $132(44.0 \%)$ & $60(20.0 \%)$ & $23(7.7 \%)$ \\
\hline 11 & $\begin{array}{l}\text { Lack of information about published } \\
\text { journal }\end{array}$ & $49(16.3 \%)$ & $114(38.0 \%)$ & $105(35.0 \%)$ & $32(10.7 \%)$ \\
\hline
\end{tabular}

Strongly Agree (SA), Agree (A) and Disagree (D) and Strongly Disagree (SD)

Source: (Authors' Compilation)

Evidence from Table 5 shows that only $61 \%$ of the respondents believed that illiteracy has a significant influence on students reading habits. Investigating the table further, 4 out of every ten respondents do not believe that reduced purchasing power can affect students' reading habits. Although $70 \%$ of the sample respondents believed that a weak education system and inadequate library system influence students' reading habits. The lack of adequate educational resources such as the library conditions and lack of library facility influenced almost half of the respondents, not believing that lack of information about published journals is an influence on students' reading habits.

\section{CONCLUSION}

Reading is the bedrock of any formal form of education. It is a cornerstone of any academic endeavour or success. It is the fulcrum or cornerstone of literacy, and without it, there can be no literacy. Reading is a communication process in which information is transmitted from a writer to a reader. The transmission can be through written symbols, which the reader decoded as a result of experience. It is at the school setting that the importance of reading is best appreciated because books constitute the bulk of learning resources. Student's success depends on the extent to which he/ she can obtain information from prints quickly and efficiently. 
Reading is one of the most fundamental components of school curricula. It involves the recognition and understanding of the nature of the linguistics symbols that constitute written language. Reading is an active process that requires full concentration and thinking ability of the reader. Reading proficiency is the royal road to knowledge; it is essential to success in all academic subjects. It is an essential means of acquiring success in formal education; reading plays a significant role. Efforts should be made to teach the pupils how to read. Kolawole (2005) also noted that reading is fundamental to learning, and so a child's ability to read is the centre of the education process. The success or failure of students is often attributed to the student attitude to reading. A student who could not read cannot benefit from formal education. The ability to read and comprehend is a skill that a student requires to be successful in his/her academic pursuit. That is why this study examined the effects of reading habits on the academic performance of students in Ibadan North local government.

The study reveals that there was a significant positive relationship between student reading habit and student academic performance $(\mathrm{r}=0.84, \mathrm{~N}=300, \mathrm{P}<$ .05 ) and at $\mathrm{F}=1.31$ and $\mathrm{P}>0.05$ there is no significant difference in the reading habit of male and female students.

\section{RECOMMENDATION}

Based on the findings from this study, the researchers suggest the following:

- The study suggests the redesigning of the study materials according to the design ideology and templates of a magazine to further encourage reading among students. The study suggests the redesigning of the study materials according to the design ideology and templates of a magazine to further encourage reading among students.

- Improved coordination and organisation of study time are suggested, as this will bring about more productive study time.

- Reading culture should be inculcated into the students at an early stage. Teachers should use teaching methods and approaches that would make students have an interest in reading. The parents, the teachers, and curriculum developers should play their part collectively and individually in developing interest, positive perception, and attitude of students towards reading.

- The government should provide an enabling environment that will stimulate students to read. The media, in conjunction with curriculum developers, should develop programmes that would develop, enhance, and promote excellent reading habits in the students. 
The researchers believe that if these recommendations are implemented holistically, the reading habit of students will be further enhanced hence impacting their academic performance.

\section{REFERENCES}

Abdu-Raheem, B. O. (2015). Parents' Socio-Economic Status as Predictor of Secondary School Students' Academic Performance in Ekiti State, Nigeria. Journal of Education and Practice, 6(1), 123-128.

Adebajo, S. (2001). The Development of Yoruba Textbooks for Secondary Education in Nigeria. Journal of Cultural Studies, 3(2), 612.

Adeniyi, O., Araoye, M., Amali, E., Eru, E., Ojabo, C., \& Alao, O. (2010). Effect of Using Combination of O'level Result With JAMB Score on Student Performance in The First Two Years of Medical School in Benue State University, Makurdi. African Journal of Biomedical Research, 13(3), 189-195.

Adeyemo, C. (2005). Test anxiety, cognitions, study habits and academic performance: A perspective study. Advances in Test Anxiety Research, 7, 221-241.

Aduwa, S. E. (2004). Dynamising the Instructional System: An inquiry for effective childhood education in Nigeria. Nigerian Journal Curriculum Studies, 11(2), 239-245.

Agina-Obu, N. T., Amakiri, M. E., \& Emesiobi, P. (2011). Awareness and use of Effective Study Techniques (EST) among Secondary School Students in Rivers State of Nigeria. African Journal of Education and Technology, 1(1), 66-74.

Ahmad, H. I., Malik, K., \& Azeem, M. (2014). A Study of Reading Habit and Computer Technology Effect on Student in Pakistan. Journal of Education and Literature, 1(1), 9-19.

Ajayi, I., \& Osalusi, F. (2013). Mass Failure of Students in West African Senior School Certificate Examinations (WASSCE) in Nigeria: The Teachers' Perspective. International Journal of Case Studies, 2(4), 1-5.

Akinboye, J. O. (1974). Study habits modification, studyattitude change and academic performance (Unpublished Masters Thesis). University of Ibadan, Ibadan.

Akinsolu, A. O. (2010). Teachers and Students' Academic Performance in Nigerian Secondary Schools: Implications for Planning. Florida Journal of Educational Administration \& Policy, 3(2), 86-103. 
Albrecht, J. R., \& Karabenick, S. A. (2018). Relevance for learning and motivation in education. Journal of Experimental Education, 86(1), 1-10. doi:10.1080/0022 0973.2017 .1380593

Alimi, O. S., Ehinola, G. B., \& Alabi, F. O. (2012). School Types, Facilities and Academic Performance of Students in Senior Secondary Schools in Ondo State, Nigeria. International Education Studies, 5(3), 44-48.

Ameyaw, S. K., \& Anto, S. K. (2018). Read or perish: reading habit among students and its effect on academic performance: A case study of Eastbank senior high school-Accra. Library Philosophy \& Practice, 1-25.

Applegate, A. J., \& Applegate, M. D. (2004). The Peter effect: Reading habits and attitudes of preservice teachers. The Reading Teacher, 57(6), 554-565.

Arohunmolase, O. (2006). Globalization and the Problems and Prospects of Teaching and Learning of Yoruba as a Second Language (L2) in Colleges of Education in Nigeria. In 36th Annual Conference on African Linguistics (pp. 129-132). Cascadilla Proceedings Project.

Bertoni, E., Di Maio, M., Molini, V., \& Nistico, R. (2017). Education is forbidden: The effect of the Boko Haram conflict on schooling in Nigeria. Academic Press.

Biggs, J. B. (1970). Faculty patterns on study behaviour. Australian Journal of Psychology, 22(2), 161-174. doi:10.1080/00049537008254570

Blumende, R.(2001). Making schools effective in Nigeria. The Journal of Educational Research, 5(1), 65-78.

Bojuwoye, O.(1993). School guidance practice: An approach. Ilorin. University Press.

Brown, W., \& Holtzman, W. (1967). SSHA manual: Survey of study habits and attitudes. Psychological Corporation.

Caverly, D. C., \& Peterson, C. L. (2000). Technology in college developmental reading. In R. Flippo \& D. Caverly (Eds.), The Handbook of College Reading and Study Strategy Research. Lawrence Erlbaum Associates.

Chand, S. (2013). Study habits of secondary school students in relation to type of school and type of family. International Journal of Social Science \& Interdisciplinary Research, 2(7), 90-96.

Commeyras, N. (2001). Promoting a culture of reading. 4th Distinguished Lecture Series of Adeniran Ogunsaya College of Education. Otta/Ijanikan. 
Duruji, M., Azuh, D., \& Oviasogie, F. (2014). Learning Environment and Academic Performance of Secondary School Students in External Examinations: A Study of Selected Schools in Ota. Proceedings of EDULEARN14 Conference.

Emeke, E. A. (1984). Relationship between personal problems and study habits of Nigerian adolescents. Psychology for everyday living. A Nigerian. The Journal of Applied Psychology, 3(1), 113-130.

Erdem, A. (2015). A research on reading habits of university students:(Sample of Ankara University and Erciyes University). Procedia: Social and Behavioral Sciences, 174, 3983-3990. doi:10.1016/j.sbspro.2015.01.1145

Esther, O., \& Oluwatoyin, M. (2018). Information Communication Technology and Educational System in Nigeria: Evidence from Ekiti State Nigeria. American Journal of Information Science and Computer Engineering, 4(2), 7-18.

Ezenwafor, J., \& Amobi, S. (2016). Extent parental and student-related factors affect students' academic performance in business subjects in secondary schools in awka education zone. European Journal of Education Studies, 2(4), 234.

Federal Ministry of Education. (2004). National policy on education. NERDC.

Gbore, L. (2006a). Cognitive entry Characteristics Study Habits and Self concept as Predictor of Academic Performance of University Undergraduate Students in South West Nigeria (Unpublished Ph.D. Thesis). University of Ado - Ekiti, Ekiti.

Gbore, L. (2006b). Measuring between free time availability and student performance perceptions. Marketing Education Review, 12, 21-32.

Ghulam, M. (2013). Study behaviour, study habits, achievement motivations of university students and study advisory services. Literacy Information and Computer Education Journal, 4(1), 908-915. doi:10.20533/licej.2040.2589.2013.0133

Ibrahim, Y., Arshad, R., \& Salleh, D. (2017). Stakeholder perceptions of secondary education quality in Sokoto State, Nigeria. Quality Assurance in Education, 25(2), 248-267. doi:10.1108/QAE-04-2016-0021

Idehen, C. O., \& Oshodin, O. G. (2008). Factors affecting health instruction in secondary schools in Edo state, Nigeria. Studies on Ethno-Medicine, 2(1), 61-66. doi:10.1080/09735070.2008.11886317

Igboanusi, H., \& Peter, L. (2016). The language-in-education politics in Nigeria. International Journal of Bilingual Education and Bilingualism, 19(5), 563-578. do i:10.1080/13670050.2015.1031633 
Ikegbunam, C. (1998): Enhancing students study habits through the PR4 approach. WCCI Reg. II Forum, 2, 130 - 136.

Iyamu, E. (2005). Parents' and teachers' perception of selection as a factor of quality in the curriculum process in Nigeria. International Education Journal, 6(1), 96-103.

Jung, A. (2016). The Effect of Male Reading Role Models on the Reading Attitudes of Fourth Grade Male Students (Unpublished thesis). Graduate Programs in Education Goucher College.

Kayode, G., \& Ayodele, J. (2015). Impacts of teachers' time management on secondary school students' academic performance in Ekiti State, Nigeria. International Journal of Secondary Education, 3(1), 1-7. doi:10.11648/j.ijsedu.20150301.11

Kolawole, C. O. (2005). The State of Reading in some selected Secondary Schools in South-western Nigeria: A preliminary Report. Issues in language, Communication and Education. A book of Reading in Honour of Caroline A. Okedara. Counstellations Books.

Lasisi, M., \& Adeyanju, L. (1991). The Influence of Economic Status on the Reading Preferences of Nigerian Primary School Pupils. In Literacy and Reading in Nigeria (Vol. 5, pp. 49-58). NERDC.

Le, T., Tran, T., Trinh, T., Nguyen, C., Nguyen, T., Vuong, T., Hoang, P., Nguyen, M., Ho, M., \& Vuong, Q. (2019). Reading habits, socioeconomic conditions, occupational aspiration and academic achievement in Vietnamese junior high school students. Sustainability, 11(18), 5113. doi:10.3390u11185113

Mabekoje, O. (2005). Understanding English Grammar and Art of Communication. Enterprises.

Mansor, A. N., Rasul, M. S., Rauf, R. A. A., \& Koh, B. L. (2013). Developing and sustaining reading habit among teenagers. The Asia-Pacific Education Researcher, 22(4), 357-365. doi:10.100740299-012-0017-1

McGeown, S. (2015). Sex or genderidentity? Understanding children's reading choices and motivation. Journal of Research in Reading, 38(1), 35-46. doi:10.1111/j.14679817.2012.01546.x

McGeown, S., Duncan, L., Griffiths, Y., \& Stothard, S. (2015). Exploring the relationship between adolescent's reading skills, reading motivation and reading habits. Reading and Writing, 28(4), 545-569. doi:10.100711145-014-9537-9 
Morrison, F., \& Cooney, R. (2001). Parenting and academic achievement: Multiple paths to early literacy. In J. G. Borkowski, S. L. Ramey, \& M. BristolPower (Eds.), Parenting and the child's world: Influences on academic, intellectual, and socio-emotional development (pp. 141-160). Lawrence Erlbaum. doi:10.4324/9781410603616-8

Musah, A., \& Umar, A. A. (2017). Effects of Availability and Utilization of Biology Laboratory Facilities and Students' Academic Achievements in Secondary Schools in Yobe State, Nigeria. International Journal of Innovative Social \& Science Education Research, 5(2), 1-8.

Nwafor, C., \& Umoke, C. (2016). Evaluation of Some Approved Basic Science and Technology Textbooks in Use in Junior Secondary Schools in Nigeria. Journal of Education and Practice, 7(14), 69-78.

Obafemi, O. (2006, Mar. 19) Why reading culture is declining Sunday. Sun.

Ogunrombi, S. A., \& Adio, G. (1995). Factors affecting the reading habits of secondary school students. Library Review, 44(4), 50-57. doi:10.1108/00242539510089750

Ogunsaju, S. (2004). A Guide to School Effectiveness in Nigeria. Laville Publications.

Oheari, A. (1994). Inability to read: The bane of our public primary school pupils. Education Today: A Quarterly Journal of Finance and Income, 7(2), 2 - 4.

Ojo, O. (2003). Narrative descriptive, argumentative, conversational and dialogic speech types. In A. O. Alabi (Ed.), New perspectives in English language skills. Immaculate City Publisher.

Okegbile A. (2003). An appraisal of gender and level of primary pupils' school adjustment for national transformation. A Paper Presented At Federal College of Education Kontagora.

Owoeye, J., \& Olatunde, Y. (2011). School facilities and academic achievement of secondary school agricultural science in Ekiti State, Nigeria. Asian Social Science, 7(7), 64-74. doi:10.5539/ass.v7n7p64

Patterson, A. (1986). Leisure reading and the year eleven student. English in Austria, 75, 40-48.

Razia, B. (2015). Study habits of secondary school students in relation to their socio-economic status and gender. International Journal of Social Sciences and Management, 2(1), 68-73. doi:10.3126/ijssm.v2i1.11815 
Scales, A. M., \& Rhee, O. (2001). Adult reading habits and patterns. Reading Psychology, 22(3), 175-203. doi:10.1080/027027101753170610

Sheorey, R., \& Mokhtari, K. (1994). The reading habits of developmental college students at different levels of reading proficiency. Reading Improvement, 31(3), 156-166.

Stanchfield, J. M., \& Fraim, S. R. (1979). A follow-up study on the reading interests of boys. Journal of Reading, 22, 748-752.

Suleiman, Y., Abubakar, Y. A., \& Akanbi, I. M. (2019). Addressing the Factors Responsible for Schooling without Learning in Primary and Secondary Schools in Nigeria. International Journal of Synergy and Research, 7, 161-178. doi:10.17951/ ijsr.2018.7.0.161-178

Summers, K. (2013). Adult reading habits and preferences in relation to gender differences. Reference and User Services Quarterly, 52(3), 243-249.

Taylor, B., Barlow, S., \& Cunningham, R. (2017). Market systems development in education? An experimental case from Nigeria. Enterprise Development \& Microfinance, 28(4), 284-304. doi:10.3362/1755-1986.15-00032

Tella, A., \& Akande, S. (2007). Children's reading habits and availability of books in Botswana primary schools: Implications for achieving quality education. The Reading Matrix, 7(2). Retrieved May 2013, from http://www.readingmatrix.com/ article/adeyinka/article/pdf

Umameh, M. A. (2011). A Surveyoffactors responsible for students' poorperformance in mathematics in senior secondary school certificate examination (SSCE) in Idah local government area of Kogi state, Nigeria (Unpublished M. Ed Thesis). University of Benin, Benin City.

Usman, Y. D. (2015). The Impact of Instructional Supervision on Academic Performance of Secondary School Students in Nasarawa State, Nigeria. Journal of Education and Practice, 6(10), 160-167.

van Bergen, E., van Zuijen, T., Bishop, D., \& de Jong, P. (2017). Why are home literacy environment and children's reading skills associated? What parental skills reveal. Reading Research Quarterly, 52(2), 147-160. doi:10.1002/rrq.160

Vipene, J. (2005). Introduction to Psychological Foundation of Education. Port Harcourt: Harey Publications.

West African Examinations Council. (2009). Statistics of Examination result. Nigeria: West African Examinations Council Lagos. 
Williams, A. (2017). Promoting quality control in Yoruba Language textbooks for primary schools in Nigeria. Interdisciplinary Journal of African and Asian Studies, $1(2), 1-9$.

Womack, S., \& Chandler, B. (1992). Encouraging reading for professional development. Journal of Reading, 35(5), 390-394.

Wood, R. W., Zalud, G. G., \& Hoag, C. L. (1995). Reading habits of elementary school teachers and principals. Reading Improvement, 32(4), 220-226.

Yani, S. (2003). Reading habits of senior secondary school students in Zaria local government area. Zaria Journal of Librarianship, 6(1\&2), 30.

Yusuf,F.(2007). Repositioning school libraries in Nigeria: The catalystfor promoting reading habits among primary and secondary school students. Academic Press. 